\title{
Флексибилната бронхоскопия за екстракция на чужди тела в детската възраст - възможности, предимства и недостатъци
}

\author{
Д. Николов, Н. Криворов, И. Йовчев \\ Катедра УНГ-болести, МУ - Пловдив
}

\section{Резюме}

Задачи: Да се оцени опитът, предимствата и недостатъците на флексибилната бронхоскопия (ФБС) при екстракцията на трахеобронхиални чужди тела (ТБЧТ) при деца на възраст до 16 години по материали на клиниката за 10-годишен период от 2001-2010 г.

Дизайн: Разгледахме ретроспективно всички бронхоскопии, извършени през този период при деца, хоспитализирани със съмнение за аспирация на ТБЧТ. Анализирахме информацията според вида бронхоскоп, използван при екстракцията (ригиден или флексибилен, или комбинацията от двата), вида анестезия, успеваемостта на екстракцията, както и настъпилите при някои от тях усложнения.

Резултати: От 237 деца на възраст от 9 месеца до 16 години при 165 (69.62\%) диагностицирахме и екстрахирахме ТБЧТ. При 62 деца (29.90\%) ТБЧТ не открихме. Флексибилен бронхоскоп за екстракция използвахме при 68 деца (28.69\%) ФБС екстракция използвахме главно под обща анестезия през отворена ригидна бронхоскопска тръба, основно когато чуждото тяло беше извън обсега на ригидната бронхоскопия или в процеса на екстракция части от него мигрираха в дисталните отдели на трахеобронхиалното дърво. ФБС използвахме и в случаите, когато се налагаше повторна бронхоскопия при персистенция на симптомите на хиповентилация, доказвани физикално или рентгенологично. Странични реакции, свързани главно с постбронхоскопски ларингеален оток, упорита кашлица, задух, наблюдавахме при 12 деца. Тези усложнения купирахме сами медикаментозно със съответните дози кортикостероиди. При едно от децата с ТБЧТ (бобено зърно) поради трудната, продължителна и травматична екстракция се наложи да бъде преведено в СРИЛ на детска хирургия и поставено на командна вентилация за 24 часа.

Заключение: Флексибилната бронхоскопична екстракция на ТБЧТ може да се използва успешно и безопасно при екстракцията на ТБЧТ . От нашия опит тя беше успешна при всички деца, при които я приложихме. Възможно е при по-големи деца над 10 години тя да бъде извършена и под местна анестезия, като съществува риск от изпускане на ЧТ при преминаването му през глотиса и настъпването на асфиксия. В такива случаи незабавно трябва да се пристъпи към ригидна бронхоскопия под обща анестезия, тоест необходимо е задължителното присъствие на анестезиолог и ендоскопистът да владее еднакво добре и двата метода за бронхоскопия.
$\mathrm{M}$ ного случаи на внезапна смърт при деца са предизвикани от аспирация на чужди тела в трахеобронхиалното дърво. През 1986 г. $12 \%$ от внезапни случаи сред деца се дължат на асфиксия от аспирация на ЧТ (1) .

Забавянето в правилното поставяне на диагнозата и лечението на ТБЧТ водят до тежки белодробни усложнения като развитието на белодробни абсцеси с неясен изход от оперативното лечение и инвалидизация на болния (2). В много случаи първоначалният драматичен инцидент на аспирация остава незабелязан от родителите или се неглижира, даже и от лекари. По тази причина диагностиката се забавя и болните се представят пред нас с картината на хронично чуждо тяло $(1,3)$.

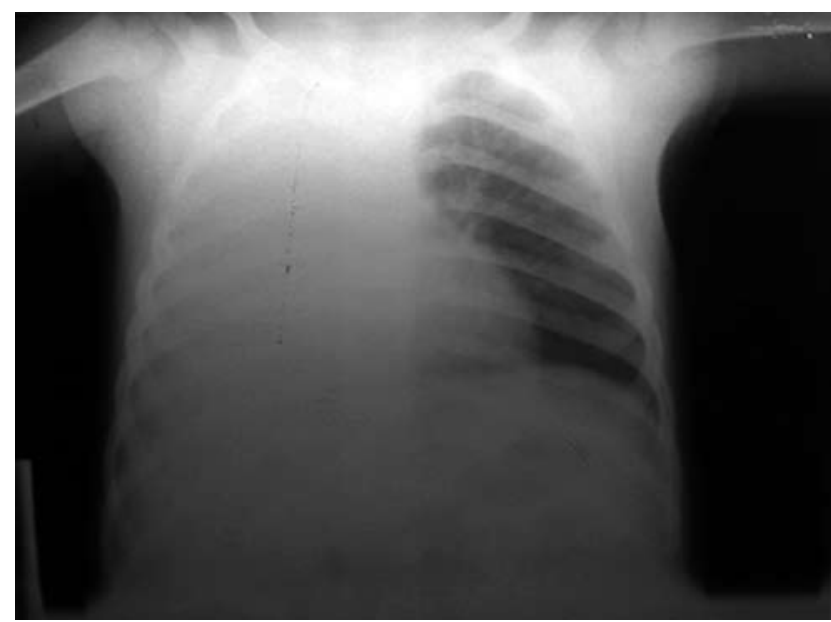

Традиционният инструмент на избор за екстракция на ТБЧТ е ригидният дихателен бронхоскоп. Процедурата се извършва под обща анестезия с релаксация от добре 
обучен екип от анестезиолози и бронхоскопист и има както диагностичен, така и терапевтичен ефект - след визуализация на ЧТ се пристьпва към незабавна екстракция. Възможността за контрол върху дихателните пътища, адекватната оксигенация, както и разнообразието от бронхоскопични щипки правят методиката рутинна и безопасна в ръцете на опитния специалист $(1,3,4)$.

След конструирането и въвеждането на флексибилния бронхоскоп през 1966 г. от проф. Икеда и миниатюризирането на апаратурата с цел приложението ѝ в педиатричната практика ФБС се превърна в основен инструмент в модерната белодробна диагностика. В последните 20 години все по-често се срещат съобщения за приложението на апаратурата и за екстракция на ТБЧТ в детската възраст.

Същевременно употребата на флексибилните апарати за екстракция на ЧТ е затруднена поради малкия размер на ендоскопа - дебелина 2-3 мм, както и тънките фиброщипки, с които те работят. Предимство на фиброоптичната апаратура е възможността за ендоскопски контрол на дисталните отдели на трахеобронхиалното дърво, тоест възможността да обозрем до устия на субсегментарни бронхи. Друг недостатьк на ФБС е, че тя се осъществява под местна анестезия и при изпускане на вече захванато ЧТ е възможна асфиксия при преминаването на апарата през глотиса. Тези недостатъци правят флексибилните апарати опасни за възникването на неконтролируеми усложнения по време на манипулациите.

През последните години авторите предлагат комбинирана ригидна и флексибилна бронхоскопия през отворена ригидна бронхоскопска тръба $(1,3$, $4,5)$.

\section{Материал и методи}

За период от 10 години - от месец май 2001 до април 2010 г., в клиниката по УНГ-болести на УМБАЛ „Св. Георги“ при 237 деца, суспектни за аспирация на ТБЧТ, сме извършили ригидна бронхоскопия. 117 от тях (49.38\%) бяха момчета и 120 (50.62\%) бяха момичета на възраст от 6 месеца до 16 години. При 175 от тях $(75.10 \%)$ бяха диагностицирани и екстрахирани ТБЧТ. Останалите 59 (24.90\%) бяха с негативна находка за ТБЧТ. При 68 деца (28.69\%) сме извършвали и флексибилна бронхоскопия през отворена бронхоскопска тръба. Ригидните дихателни бронхоскопии сме извършвали със стандартни ригидни дихателни бронхоскопи на Storz с размери 4 мм до 9 мм. За флексибилната бронхоскопия работихме с детски ФБС Pentax с ф 3.2 мм и 1.8 мм работен канал. В този апарат не разполагахме с адекватна по размер фиброщипка, поради което апарата използвахме само за оглед и аспирация. В момента работим с педиатричния ФБС Olympus c ф 2.2 мм и работен канал 1 мм, който фабрично е съоръжен с фиброщипка. Към апаратурата разполагаме и с видеомонитор и видеопроцесор за видеодокументация.

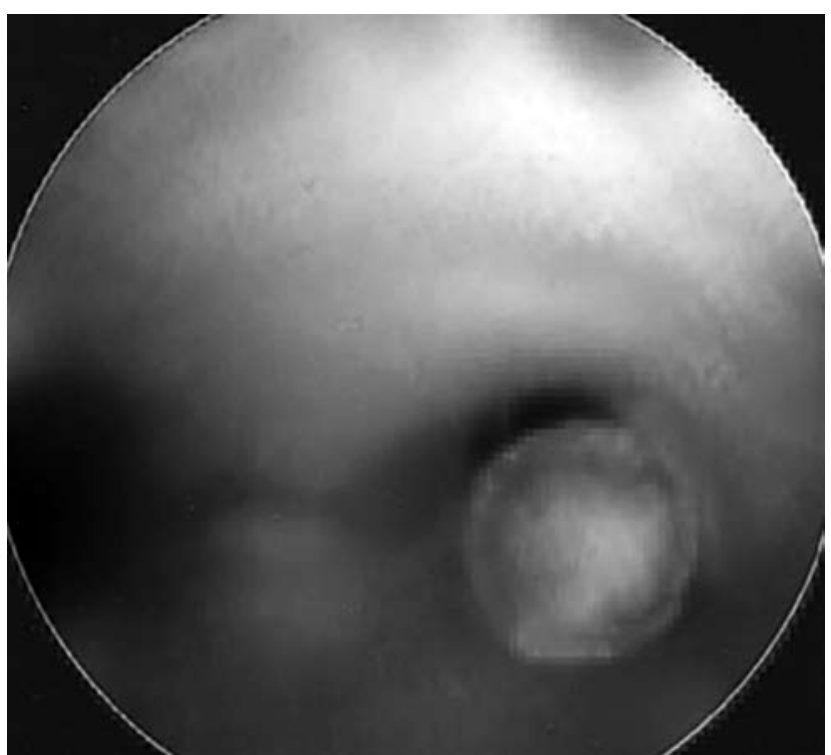

Показанията за комбинирана флексибилна и ригидна бронхоскопия поставяхме в случаите, когато се налагаше да се извьршва повторна бронхоскопия. Това срещахме в случаите, когато след екстракция на ТБЧТ в следоперативния период наблюдавахме задрьжка на физикалните и рентгенологичните симптоми на хиповентилация от страна на екстрахираното ТБЧТ. В тези случаи при повторната бронхоскопия през отворения тубус на ригидната тръба въвеждахме флексибилния бронхоскоп. Визуализирахме ЧТ, от което обикновено откривахме малки остатъци, мигрирали в дисталните отдели на трахеобронхиалното дърво, залавяхме с фиброщипка и го изваждахме до лумена на ригидната тръба. След това двата апарата извличахме заедно. По този начин предотвратявахме изпускането на ЧТ от нежната фиброщипка при преминаването му през глотиса. 


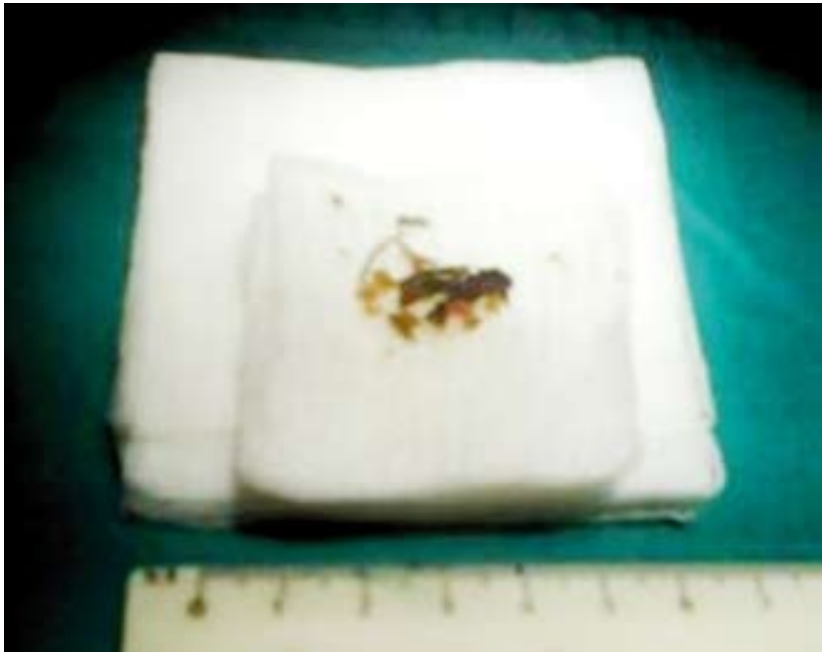

При 6 деца (2.53\%) на възраст от 12 до 14 години извършихме екстракция на ЧТ, използвайки техниката на ФБС местна анестезия, залавяйки ЧТ с фиброщипка. При 2 от тези деца ЧТ бе изпуснато от захвата на фиброщипката, което наложи повторна ригидна бронхоскопия по стандартния начин с обща анестезия.

При 62 (29.9\%) от всички 237 деца не открихме ЧТ. В тези случаи също прилагахме и допълнително фиброскопски оглед, за да визуализираме и дисталните отдели на трахеобронхиалното дърво. Това ни даваше сигурност в поставянето на негативна бронхоскопска диагноза за ЧТ.

\section{Обсъждане}

Традиционно ригидната бронхоскопия е средство на избор за екстракция на ТБЧТ при деца. Предимствата на ригидния бронхоскоп са, че може да бъде използван и като ендотрахеална трьба за вентилация, дава възможност на работещия екип от анестезиолог и ендоскопист да осигуряват адекватен контрол на дихателния път и адекватната оксигенация по време на интервенцията. Независимо от това, че методът се е доказал в исторически план, той не е достъпен за всички медицински центрове.

\section{Литература:}

1. Wood, RE Flexible bronchoscopy to remove foreign bodies in childrenyes, may be-but [editorial]. J Bronchol 1994; 1,87

2. Swanson, KL, Prakash, UB, Midthun, DE, et al. Flexible bronchoscopic management of airway foreign bodies in children. Chest 2002; 121: 1695 .

3. Swanson, KL, Prakash, UB, Midthun, DE, et al, Foreign bodies in children's airways. Hong Kong Med.J.; vol. 15 N1; February 2009
Флексибилният бронхоскоп в детските му варианти е по-широко разпространен . Фиброоптиката дава възможност за по-детайлна визуализация на трахеобронхиалното дърво в дисталните му отдели. Тоест детайлната диагностика е с по-големи възможности. Недостатъците са, че фиброоптичната екстракция крие известни рискове и според нас трябва също да се извършва с обща анестезия, ако не през ригиден дихателен бронхоскоп, то поне през стандартна ендотрахеална тръба за интубация. Поради нежните фиброщипки, с които се работи, вероятността от загуба на контрол върху ЧТ при неговата екстракция е по-голяма. В такива случаи е необходима реинтубация и завършване на процедурата по стандартен начин. Възможностите на ФБС при екстракция на ЧТ от трахеобронхиалното дърво трябва да се обсьждат при по-големи деца, според нашия опит - над 10-годишна възраст.

\section{Изводи}

От нашия опит ние предлагаме следния алгоритъм:

1. Ригидна бронхоскопия при всеки един от случаите на:

- асфиксия

- рентгенпозитивно чуждо тяло, особено ако е с остри ръбове

2. Гъвкава бронхоскопия във всички останали случаи, както и в случаите, когато се налага извършване на повторно бронхоскопско изследване.

3. За предпочитане е анестезията да бъде обща или ако се прибегне до местна анестезия, то задължително манипулацията трябва да се извърши в операционна зала с възможност за незабавно преминаване към обща анестезия.

4. Желателно е екипът, който работи, да бъде обучен и на двата метода - флексибилна и ригидна бронхоскопия. В противен случай се налага манипулацията да се повтори, което не е в интерес на болното дете.

4. Martinot, A, Closset, M, Marquette, $\mathrm{CH}$, et al Indications for flexible versus rigid bronchoscopy in children with suspected foreign-body aspiration. Am J Respir Crit Care Med 1997; 155, 1676-1679

5. Dikensoy O, Usalan, Filiz . Foreign body aspiration: clinical utility of flexible bronchoscopy. Postgraduate Medical Journal. 78(921): 399403, July 2002.

Настоящата публикация е част от научен проект ДО02.349/29.12.08 г. „Интегриран научно-изследователски иентър по детско здраве“, осъществяван с финансовата подкрепа на Фонд „Научни изследвания“ към МОН. 